\title{
Different ideas for textile fashion market and sustainability - environmental \& economical costs of fashion products
}

\begin{abstract}
The 21 st century has been good to for the apparel industry \& Textile Fashion Market and development of advance technology in Fashion industries increases production as well as style and rang of the Fashion products, rising the regular consumer through the many study find out the clothing production ratio was doubled from 2000 to 2014, and the number of garments purchased each year by the average consumer increased by 60 -70 percent. Now days in Fashion industries production policy work on no return that is a major impact of the "fast-fashion". Fast Fashion trend production is very much appreciated by retailers, consumer as well as all over product life cycle chain because of that is a beneficial for ever-growing need to produce more, produce faster, produce cheaper, and respectively sell more, faster and cheaper fashion products.
\end{abstract}

But one of the negative costs of the fast fashion production consumer buying power increase due to the advance growth in tine fashion production that's result the final impact on the environment occurs during the more disposal phase of the used products. Clothing waste is a contributing factor to the stress placed on landfills, with further negative implications for soil, water and air quality. Theoretically most waste textiles are recyclable; however, there is no well established recycling system for textiles and Fashion products. Only about $20 \%$ can be recycled due to current technique and economic constraints

In this paper researcher try to find out the fact that sustainable consumption is an issue that needs to be addressed in terms of waste reduction, resource conversion, and control of pollution.

Keywords: sustainability, aesthetics, appearance, uniqueness, fashion industry, textile industry, supply chain management, green supply chain, clothing retailers, consumer behavior, ethical consumerism, fair trade, choice editing, focus groups, qualitative research, retail trade, corporate social responsibility, customer satisfaction, slow fashion, consumption, fast fashion, apparel, environmental impacts, life-cycle assessment
Volume 4 Issue 6 - 2018

Smriti Agarwal

Amity School of Fashion Technology, Amity University Rajasthan, India

Correspondence: Prof. Smriti Agarwal, Amity School of Fashion Technology, Amity University, Rajasthan, India, Email sagarwel@jpr.amity.edu

Received: November 14, 2018 | Published: December 18, 2018

\section{Introduction}

More the famous fashion brands in Apparel sectors were blamed for the non sustainability of the environment. Nonetheless, many companies are very much conscious for the conservation of the environment and green practice. As fashion industry has huge impacts on global environment, conscious consumers are growing social and environmental awareness which has a direct influence in the co-fashion consumption impacts throughout the lifecycle chain: from growing and harvesting crops, coloration, garment manufacture, transportation (takes place between each phase of production), customer use, and to eventual disposal of goods. "Fashion as usual" increases speed and magnitude of resources use, influences redistribution of natural components together with intrusion of waste and emissions to air, water and land. In this Report try to Highlighted the fact that sustainable consumption is an issue that needs to be addressed in terms of waste reduction, resource conversion, and control of pollution. And another one of the concern focuses on waste management: minimizing waste and maximizing reuse and recycling of environmentally sound waste. Reuse or recycling of discarded fashion items reduces the environmental impact significantly compared to the purchase of new fashion products. It has been found that approximately $30 \%$ of energy is saved for new development of fiber and yarn replaced by used clothing. Based on the study, this paper presents an overview of three end-of-life waste management strategies 3R: Reusing, Recycling and Refashioning. ${ }^{1-3}$

\section{Findings}

a. Fast fashion products can be reused by the common people of the society for the necessity of clothing or retailers can sell them in the second hand clothing market in cheaper prices (which is being on practices in the third world, least developed counties these types of products are basically used by the marginal people of the society where cheaper price is the only factor to choose the product by the customers. From the recycled products, customers sometimes make the redesign, reshape as per the requirement. For this, local techniques and local labor are used which is another chance of increasing the scope of employment in the market and to fulfill the market demand. On the contrary, hot marketing fashion products are reused by the common person; that is the ultimate saving of the new garments, required from the fashion market. Not only that, it also saves the use of thousand tons of raw materials for the 
manufacturing of new garments that is increasing the market demand of raw material for increasing the price of the products.

b. Clothing consumption in India instance has increased by almost 60 percent by the impact of Fast Fashion culture and develop many manufacturing units in market another reason is price choice are also available in every budget according to consumer, and Research data shown each Indian on average buys $15-30 \mathrm{~kg}$ of fabric each year. Garments here are more quickly discarded as a result of changing fashion than because of wear and tear. Same time, on other side of the Earth fastfashion businesses continue to take advantage of the poor and low living standards. Human rights and basic needs are often neglected, most of workers are doing their job in inadequate and inhumane conditions for those type of people buy recycled apparels on low cost Recycle product Industries develop addition alteration techniques for mass sell our product on low investment.

c. Develop Apparel Collection System-In India approximate $40 \%$ apparel as a wastage destroy in environment of the total used sustainable development two primary stagey develop by the government as well as private industrial also very important for the same for increase sustainability to develop waste stream and market drive system in both system develop such type of techniques those are motivate to user for submission of used apparels for recycling/ reuse \& refashion able. ${ }^{4,5}$

\section{Conclusion}

This study provides useful models for understanding the reusing, recycling and refashioning processes as currently practiced in the industry. The study also suggests that there is potential for greater stakeholder interaction in developing alternative business models for waste diversion. Currently, many waste collectors depend on the waste stream to collect disposed textiles and clothes and they have to be ready to accept all the waste the fashion industry produces. It is now time for retailers to address the issue of fashion industry waste in a more responsible manner. Both retailers and manufacturers must make an effort to develop market-driven product recovery systems in order to support the growth of closed-loop supply chain systems. Government could play a key role in maximizing waste diversion and recovery opportunities by introducing policies and regulations for manufacturers, retailers and consumers. Introducing landfill bans will not solve the entire problem unless

A. Manufacturers are encouraged to produce more easily recyclable materials.

B. Entrepreneurs are supported to develop new business models for secondary use of textiles

C. Consumers are encouraged to buy fewer, but more durable products.

Otherwise consumers will continue to buy at a profligate rate, and excessive levels of waste will continue to accumulate locally and globally, thus creating and compounding further issues in the management of waste.

\section{Acknowledgments}

None.

\section{Conflicts of interest}

Author declares there is no conflict of interest in publishing the article.

\section{References}

1. Junghyun Jang, Eunju Ko, Eunha Chun, et al. A Study of a Social Content Model for Sustainable Development in the Fast Fashion Industry. Journal of Global Fashion Marketing: Bridging Fashion and Marketing. 2012;3(2):61-70

2. Lea-Greenwood LB. Fast fashioning the supply chain: Shaping the research agenda. Journal of Fashion Marketing and Management. 2006;10(3):259-271

3. Monika Holgar, Marcus FR. Fashion as a Communication Medium to Raise Environmental Awareness and Sustainable Practice. Australian and New Zealand Communication Association Conference. Brisbane, Queensland: Queensland University of Technology; 2009.

4. Monsoon. Facing the future together. 2011.

5. Morrissey AJ, Browne J. Waste management models and their application to sustainable waste management. Waste Management. 2004;24(3):297308 . 